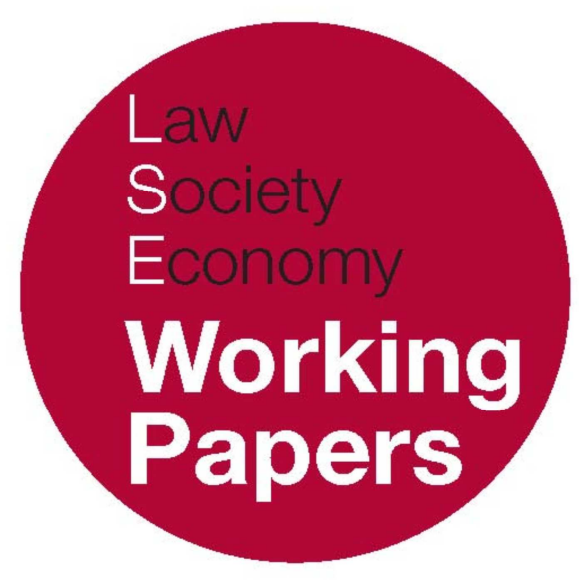

\title{
Intermediated Securities and Legal Certainty
}

\author{
Eva Micheler
}

LSE Law, Society and Economy Working Papers 3/2014

London School of Economics and Political Science

Law Department

This paper can be downloaded without charge from LSE Law, Society and Economy Working Papers at: www.lse.ac.uk/collections/law/wps/wps.htm and the Social Sciences Research Network electronic library at: http://ssrn.com/abstract $=2336889$.

(C) Eva Micheler. Users may download and/or print one copy to facilitate their private study or for non-commercial research. Users may not engage in further distribution of this material or use it for any profit-making activities or any other form of commercial gain. 


\title{
Intermediated Securities and Legal Certainty
}

\author{
Eva Micheler
}

\begin{abstract}
This contribution shows that holding securities through chains of intermediaries compromises the ability of investors to exercise their rights. This problem is not remedied by Geneva Securities Convention ('the Convention' or 'GSC'). It will be argued in the paper that research should be carried out to determine if a mechanism can be created that enables ultimate investors to hold securities directly. Further work on creating a harmonized set of rules at a functional level will not improve legal certainty, reduce systemic risk or enhance market efficiency. The problems associated with the current framework are a function of the process of intermediation itself. Legal and systemic risk and market efficiency are adversely affected by the number of intermediaries operating in this context. Law cannot help here. Structural reform can. It is worth investigating if a framework can be created that allows for securities to be held directly by ultimate investors.
\end{abstract}

\footnotetext{
* Reader in Law, London School of Economics and Political Science. A version of this paper will appear as a chapter in Thomas Keijser, Transnational Securities Law, OUP 2014.
} 


\section{A. INTRODUCTION}

The purpose of this contribution is to analyze the rules on transfers of securities contained in the Geneva Securities Convention ('the Convention' or 'GSC'). The analysis will be carried out by reference to the shortcomings the Convention was designed to address. It will be shown that, instead of perpetuating existing levels of intermediation by creating more harmonized rules on intermediated holdings, research should be carried out to determine if a mechanism can be created that enables ultimate investors to hold securities directly. Further work on creating a harmonized set of rules at a functional level will not improve legal certainty, reduce systemic risk or enhance market efficiency. The problems associated with the current framework are a function of the process of intermediation itself. Legal and systemic risk and market efficiency are adversely affected by the number of intermediaries operating in this context. Law cannot help here. Structural reform can. It is worth investigating if a framework can be created that allows for securities to be held directly by ultimate investors.

The chapter will also briefly discuss the target2securities project that has recently been set up by the European Central Bank. The aim of the project is to create a computer programme that will link intermediaries with each other. This will make it possible for securities to be transferred between intermediaries using a common set of technical specifications. The hope is that this will reduce settlement cost and also kick start competition between existing providers. The chapter will show that the target2securities project is unlikely to reduce numbers of intermediaries and that the current momentum should be used to investigate if a direct holding system that spans across borders can be created.

This chapter will begin with an analysis of the shortcomings that the Geneva Securities Convention was designed to address. It will be shown that the study group intended for the Convention to create a framework for reform that would remedy specific instances of legal uncertainty. It was also hoped that the Convention would assist developing countries to put in place appropriate legal rules. The negotiations between the member states of UNIDROIT, however, have led to the Convention containing a set of rules that are common to a considerable number of jurisdictions rather than a set of rules that address particular instances of legal uncertainty that were previously identified.

The result is that the Convention provides jurisdictions with inspiration as to roughly what kind of outcomes their law should aim for. It does not, however, enable those drafting documentation, legal advice or national legislation to put in place solutions that are more certain than the solutions already in place.

The thesis of this chapter is that legal uncertainty is created by intermediation itself and that it increases with each intermediary that is added to the chain. It is time to discuss structural reform that reduces the number of intermediaries and also enables issuers and ultimate investors to communicate directly. It seems that it 
should be possible to create a model for holding and transferring securities that provides for a transparent link between issuers and ultimate investors.

\section{B. SHORTCOMINGS OF THE CURRENT ARRANGEMENT}

In order to determine what contribution the GSC has made and what further contribution can be made in this area of the law, it is worth remembering the context in which the work on the Convention started. At the time a number of reports were published that identified significant problems in relation to the transfer and holding of securities at a global level and also across Europe. ${ }^{1}$ These were the fact that there are too many intermediaries, that differences in market practice and law increase cost and the fact that the legal regimes supporting the settlement infrastructure contained legal uncertainty. These problems will be discussed in turn below.

\section{(1)}

\section{TOO MANY INTERMEDIARIES}

One concern that was raised was the number of intermediaries operating in this branch of the financial services industry. The Lamfalussy report highlighted that 'a large number of transaction and clearing and settlement systems [...] fragment liquidity and increase cost, especially for cross border clearing and settlement'.2 Reports were cited according to which cross border settlement within the EU was ten times more expensive than settlement in the US through the centralized Depository Trust \& Clearing Corporation. The gap was even larger when central counterparty and clearing services were added to the analysis. ${ }^{3}$ The first Giovannini report observed that the EU infrastructure in clearing and settling trades is 'highly fragmented'. When the Giovannini report was written, there existed across Europe 19 local entities and two international entities whose primary business it was to play a role in clearing and settlement. ${ }^{4}$

The situation is not much different at present. The European Central Bank put together material illustrating the complexity of settlement in Europe in comparison with the relatively straightforward settlement mechanism in the US and lamenting the 'very high cost of cross-border settlement' as well as the

\footnotetext{
${ }^{1}$ Kanda et al., Official Commentary, Int-4.

2 Final Report of the Committee of Wise Men on the Regulation of European Securities Markets (February 2001) 10, available at http://ec.europa.eu/internal market/securities/lamfalussy/index en.htm (last visited 4 September 2013).

3 Lamfalussy Report, 82; see also Alberto Giovannini, 'Cross-Border Clearing and Settlement Arrangements in the European Union' (November 2001), excerpt from the foreword and p ii. The Giovannini report is available at http://ec.europa.eu/economy finance/publications/publication summary8035 en.htm (last visited 4 September 2013).

${ }^{4}$ First Giovannini report, pp i-ii.
} 
'complex settlement procedures and high level of risk'.5 The 2012 Kay Review stressed that the cost of holding intermediated securities and carrying out transactions with them increases with the number of intermediaries involved. Each of them must cover the cost of operating facilities and employing staff and on top of that most intermediaries must earn sufficient money to reward their investors. ${ }^{6}$

Intermediation also increases legal risk. Each of the intermediaries forming a particular chain uses documentation. This documentation should operate to pass the interest from the issuer to the ultimate investor. Complete synchronization is, however, impossible to achieve. Notwithstanding careful drafting, it is impossible to pass down an interest from an issuer to the ultimate investor through several layers of intermediation without friction.

The limitations of documentation in chains of intermediation have recently been illustrated by the UK High Court decision in Eckerle $v$ Wickeder Westfalenstabl GmbH which was decided on 23 January 2013.7 The case concerned a public limited company incorporated in England (DNick Holding plc). It was managed and operated from Germany. Its shares were only listed in Germany. The directors of the company decided to cancel the German listing and to convert the company from a public limited company to a private limited company. It called an extraordinary shareholder meeting where a resolution was passed approving the re-registration of the company as a private company. This was opposed by three minority shareholders. They tried to rely on the UK Companies Act 2006, s 98. According to this section, 'the holders of not less in the aggregated than $5 \%$ in nominal value of the company's issued share capital' may apply to court for a cancellation of the resolution. On the hearing the court may make an order cancelling or confirming the resolution. It may also make an order that an arrangement may be made to the satisfaction of the court for the purchase of the interests of dissentient members.

Shares in listed companies are worth more than shares in private companies. The lack of a ready market in which minority shares can be sold reduces the number of willing buyers. The value of the shares of the minority shareholders was therefore reduced as a result of the delisting. Normally this problem would be addressed by take-over rules. It appears that the shareholders in Eckerle were not protected by the UK or the German takeover rules. The minority shareholders therefore relied on CA 2006, s 98. They wanted to be bought out. To benefit from that section they had to show that they were 'holders' of at least $5 \%$ of the share capital. They held $7.2 \%$ of the shares or at least they thought they did.

The problem in this case was that the investors' names were not on the shareholder register. The register of shareholders mentioned Dr Platt holding 1

${ }_{5}$ Available at http://www.ecb.int/paym/t2s/about/shared/img/eu-trading-landscape.jpg (last visited 4 September 2013).

6 The Kay Review of UK Equity Markets and Long-Term Decision Making, Final Report, July 2012 available at: $<$ http://www.bis.gov.uk/kayreview $>$ Para 3.7 (last visited 4 September 2013).

7 [2013] EWHC $68(\mathrm{Ch})$. 
share and The Bank of New York Depository (Nominees) Ltd holding 5,671,317 shares. BNY held the shares on trust for Clearstream AG. Clearstream AG kept accounts through which it held 'Clearstream Interests' for its account holders. These were held through Clearstream AG accounts. Clearstream account holders are not individuals but banks or other financial institutions. These act for other banks or financial institutions or the ultimate beneficiary. ${ }^{8}$

The ultimate German investors wanted to exercise rights under the English Companies Act to be bought out upon re-registration of the company. Justice Norris found that the claimants were not literally speaking the holders of $7.2 \%$ of the shares, they were only holders of 'the ultimate economic interests in underlying securities amounting to a specified percentage of shares held by BNY on trust for Clearstream account holders whose customers the claimants are'. This was not good enough for them to be able to exercise rights under Companies Act 2006, s 98.

The documentation used in that case apparently tried to address this problem, but failed. It is possible for an English registered company to make provisions in its articles enabling a member to nominate another person or persons as entitled to enjoy or exercise all or any specified rights of the member in relation to the company (CA 2006, s 145). In Eckerle, the articles contained such provisions. Article 79.2 of DNick's articles provided that 'each person who is a CI [Clearstream Interest] holder' can either direct the registered holder of the share how to exercise the vote attaching to the relevant underlying share or to appoint a proxy to do so. It appears that the ultimate investors attempted to persuade the judge that they were able to rely on this provision arguing that they were holders of Clearstream Interests. ${ }^{9}$

They failed because the definitions contained in the articles defined the term 'CI Holder' as the holder of 'an interest in the shares in the capital of the Company traded and settled through Clearstream'. They are identified on 'the electronic register of CI Holders [...] maintained by Clearstream'. The judge found that ' $[t]$ he only interests traded and settled through Clearstream are the interests of Clearstream account holders. Only banks and financial institutions which are Clearstream account holders, and between whom those trades are conducted and settled on the exchange, and whose trades are recorded on the electronic register, fit this description. ${ }^{\prime 10}$

To an English lawyer this conclusion is obvious. A German lawyer looking at the articles of DNick Holdings would be forgiven for not spotting this as a problem. The German model, which in this respect would seem to also apply to foreign securities (albeit on the basis of the German notion of Treuband), assumes that the ultimate investor has an interest in the underlying instrument. This is evidenced by the fact that DNick shares were listed with a UK securities number on the German stock exchange which can only mean that even the German listing

${ }^{8}$ Eckerle v Wickeder Westfalenstabl GmbH [2013] EWHC 68 (Ch) para 14 (d).

${ }^{9}$ Eckerle v Wickeder Westfalenstabl GmbH [2013] EWHC 68 (Ch) para 14 (h).

${ }^{10}$ Eckerle v Wickeder Westfalenstabl GmbH [2013] EWHC 68 (Ch) para 14 (h). 
authorities thought that UK shares were listed. This is remarkable because it was impossible for DNick shares to be listed. These shares were owned by Dr Platt and the nominee company. Clearstream only held a beneficial interest, but was not a shareholder. It can be speculated that the German investors also thought that they held UK shares only to find out that English law would not recognize them as shareholders.

What Eckerle demonstrates is that drafting mistakes happen even when two legal systems are connected that have a very sophisticated set of rules, are close to each other and between which there is frequent interaction. We can assume that the lawyers drafting the documentation for Clearstream and the other intermediaries knew the law well and tried their very best in good faith to advise their respective clients.

The problem is that documentation is bilaterally agreed between the parties of the contract. In an intermediation chain there is a contract (contract 1) between the Central Securities Depository (CSD) and the intermediary directly connected with the CSD (Intermediary 1). Intermediary 1 then has a contract (contract 2) with Intermediary 2. Intermediary 2 has a contract (contract 3) with Intermediary 3. Intermediary 3 has a contract (contract 4) with Intermediary 4. To stop here let's assume that Intermediary 4 has a contract (contract 5) with the ultimate investor.

Contract 1 is negotiated with the advice of lawyers acting for the CSD and Intermediary 1 respectively. The lawyers owe their duties to their clients. They are not instructed by the ultimate investor or by anyone else further up the chain. It is their mandate to protect the interests of Intermediary 1 and the CSD respectively. It is not within their remit to determine if contract $2,3,4$ or 5 are written in a way that adequately synchronizes them with contract 1 . The lawyers drafting contract 1 do not owe a duty to the ultimate investor requiring them to ensure that all contracts synchronize so that the interests is passed down without friction to him.

Contract 2 is then written with the help of lawyers acting for Intermediary 1 and 2 respectively. Again, the lawyers advising the parties are bound by their professional duties to look after their respective clients only. At this level the lawyers of Intermediary 1 need to make sure that contract 2 fits with contract 1 , but this synchronization does not necessarily work for the benefit of the ultimate investor. The lawyers of intermediary will ensure that Intermediary 1 does not expose itself to liability by promising anything to Intermediary 2 that it cannot deliver with a very high degree of certainty. Erring on the side of caution the lawyers would be forgiven for causing Intermediary 1 to owe a smaller set of duties to Intermediary 2 than the CSD owes to Intermediary 1. They would, for example, ensure that their client has a reasonable amount of time for the passing on of instructions or payments to the level immediately below or above them. They would also reject liability for any mistakes that happen at other levels. Taken together time and mistakes add up to the detriment of the ultimate investor. 
The process of drafting documentation repeats itself at each level that is added to the chain. This has the effect of watering down the interest of the ultimate investor. If ultimate investors are retail customers they are likely to accept the standard terms offered to them by the intermediary they have chosen. Even if an ultimate investor is able to and interested in negotiating the terms of contract 5 which he enters into with Intermediary 4 , he does not have the right to see contracts 1,2, 3 or 4 or request amendments to these contracts.

Even at national level each layer of documentation that is added to the chain inserts new uncertainty. This is notwithstanding the fact that the lawyers concerned will have a similar understanding of the legal rules.

Linking multiple contracts across more than one jurisdiction is even more difficult. ${ }^{11}$ The reason is that local legal systems are underpinned by legal rules that are difficult to understand from an outsider's perspective. For example English law uses trust law to analyze the holding of intermediated securities. This makes it difficult for lawyers from outside the common law world to understand which rights investors have and how these rights are transferred. The German analysis maintains that possession in securities documents changes when they are transferred in circumstances where there exists only one global certificate which is stored centrally. Most German lawyers will be able to fully understand all the implications of this approach. English lawyers will find it difficult to have the same level of understanding of the German rules. The fact that the lawyers writing the documentation will have a limited understanding of foreign rules on securities will be reflected in the way the documentation is drafted and that creates legal uncertainty. It would seem that harmonization of law can help here. If rules become more similar across borders, the potential for misunderstanding foreign rules could be reduced.

\section{(2) Differences in Market Practice and Law InCREaSe Cost}

Cost in relation to cross border transactions is also high because of differences between the different national providers, 'that provide very different types of services, have different technical requirements/market practices, and operate within different tax and legal frameworks'. To overcome these differences, market participants must pay for 'extra back-office facilities' to operate the various systems. Differences in market practice and law also create 'opportunity costs in the form of inefficient use of collateral, a higher incidence of failed trades and trades that are simply foregone because of the difficulties involved in post-trade processing across borders'. ${ }^{12}$

\footnotetext{
${ }^{11}$ For a recent illustration of this problem see Eckerle v Wickeder Westfalenstabl GmbH [2013] EWHC 68 (Ch).

${ }^{12}$ First Giovannini report, $\mathrm{p}$ ii; Oxera, Monitoring prices, costs and volumes of trading and post trading services (MARKT/2007/02/G) Report prepared for the European Commission DG Internal Market and Services, May 2011; the problem of different market practice has also been recently recognized by the ECB which is currently trying to harmonize market practice through the target2securities project, available at https://www.ecb.int/paym/t2s/html/index.en.html, (last visited 4 September 2013).
} 
Differences in law require market participants to arrange for legal advice explaining and evaluating the rules applicable in other countries against the background of the national framework. Legal opinions cost money. This cost is higher if the system the opinion relates to is substantially different from the system for which the opinion is required. It will take lawyers longer and will require more input from and interaction with local counsel if there are significant differences between the two. It is possible for such differences to cause investors to conclude that a transaction cannot go ahead for reasons of legal uncertainty. In theory, making laws more similar could help to reduce this problem.

\section{(3) Legal Certainty}

Another problem that troubles this area of the law is that recent years have seen a change-over from paper to electronic settlement in many jurisdictions. This change-over needs to be absorbed by law. ${ }^{13}$ Property law has historically evolved around tangible objects that are held directly by individuals. Securities are intangibles and are transferred and held electronically and through intermediaries. The process of accommodating a new market practice is bound to create legal uncertainty. Adequate drafting of the legal framework supporting the change helps to make the transition smooth and limits the impact on market efficiency.

\section{(4) A Convention as a Means to AChieve Legal Certainty?}

While a convention is unable to reduce the number of intermediaries or operational differences between different national providers, it is possible for an instrument like a convention to help reduce problems of law and legal certainty. Three instances of legal uncertainty have been identified above. Legal uncertainty arises when multiple layers of documentation need to be synchronized in particular in a cross border context, when legal opinions about foreign systems are put together, and when property law needs to be adapted to electronic and intermediated holdings and transfers.

In principle, a convention can help to improve legal certainty in these instances. If laws are more similar, lawyers will be able to better understand the solutions implemented in other legal systems. Similarity reduces the potential for misunderstandings. The better those who create the documentation understand the systems their contracts are linking the more comprehensive and reliable the text they put together will be. Lawyers drafting the documentation necessary to establish a chain of intermediaries are likely to deliver better quality work if the differences between the systems they are linking are fewer in number. This can increase legal certainty.

${ }^{13}$ Luc Thévenoz, 'The Geneva Securities Convention: objectives, history and guiding principles' in PierreHenri Conac, Ulrich Segna and Luc Thévenoz, Intermediated Securities (CUP 2013) 6-12. 
Similarly, harmonized rules can make it easier for lawyers to write opinions evaluating a foreign system for the purposes of their clients. They will be better able to appreciate the advice they receive from local counsel if the foreign system is supported by a framework that is similar to their own framework. This can, in theory, help to improve legal certainty by improving the quality and reliability of legal opinions that support intermediated holdings of securities.

A convention can also make a contribution by providing rules that help increase levels of legal certainty at a national level. This would be the case when there are questions of uncertainty in a particular Contracting State and the convention helps to clarify these questions.

\section{AIMS OF THE GENEVA SECURITIES CONVENTION}

\section{RECITALS}

Judging from the recitals to the GSC, the drafters have attempted to address the problems that have been described above. The GSC sets out to protect persons that acquire or otherwise hold intermediated securities. ${ }^{14}$ It was designed to reduce legal risk, systemic risk and associated costs in relation to domestic and crossborder transactions involving intermediated securities so as to facilitate the flow of capital and access to capital markets. ${ }^{15}$ Other aims were to 'enhance the international compatibility of legal systems as well as the soundness of domestic and international rules on intermediated securities' and to 'establish a common legal framework for the holding and disposition of intermediated securities'. ${ }^{16} \mathrm{At}$ the beginning of the project the study group concerned set out 'to draft an international instrument capable of improving the worldwide legal framework for securities holding and transfer, with special emphasis on cross-border situations'. ${ }^{17}$ There is also evidence that the study group wanted to create a framework assisting developing countries to put in place appropriate rules..$^{18}$

\section{(2) Reflection of These Aims in the Provisions of the CONVENTION}

To further these aims, the Convention focuses on securities accounts and aims to ensure that the rights of account holders are robust in the insolvency of the intermediary and also against claims from third parties. This was considered

\footnotetext{
14 Recital 2 GSC.

15 Recital 3 GSC.

16 Recitals 4 and 5 GSC.

17 UNIDROIT 2003 - Study LXXVIII - Doc. 8, p 2.

18 UNIDROIT 2004 - Study LXXVIII - Doc. 12 (International UNIDROIT Seminar, November 2003), p 3.
} 
necessary to reduce systemic risk and to enhance market efficiency. ${ }^{19}$ Otherwise the specific rules contained in the Convention have not been explained in the Official commentary by reference to legal, systemic risk or market efficiency.

It is also worth noting that the aims stated in the recitals have been implemented adopting a 'minimalist approach'. The Official Commentary sets out that a harmonized rule was regarded to be appropriate only if it was clearly required to reduce legal or systemic risk or to promote market efficiency. ${ }^{20}$ This would suggest that thought was given to the question of subsidiarity. It would seem that the contributors to the project would identify weaknesses of the respective current domestic systems determining the particular rules that lead to legal uncertainty at the respective national levels. It would have made sense then to determine whether, to what extent and across which borders legal uncertainty exists in international transactions. The contributors would then have been in a position to identify the legal rules that cause problems in the jurisdictions concerned. Following from that, they would have assessed the gravity of the problem in light of systemic risk and market efficiency to determine whether to intervene. Only after that, thought would have been given to drafting a set of rules with a view to remedying specific problems.

There is evidence that this is how the study group intended the project to progress. At the beginning of the project the group identified a number of problems that were subject to legal risk and that had systemic implications and linked those to particular topics that they considered required regulation. ${ }^{21}$ The members of the study group also embarked on a number of fact fining missions to determine to what extent and in what particular way problems of legal certainty, systemic risk and market efficiency arose. ${ }^{22}$

The Official Commentary, however, does not set out to what extent the provisions adopted in the final text of the Convention responds to particular legal uncertainties and how the individual provisions are meant to overcome these uncertainties. It also does not contain an explanation as to which particular rules currently impact on systemic risk or market efficiency and how the Convention helps to mitigate these problems.

This may be because the drafting process of the Convention was too complex to make it possible to determine at the end which provisions relate to the problems that were identified at the start of the process. It also seems that the discussions between national delegations changed the focus of the project. There

19 UNIDroIT 2003 - Study LXXVIII - Doc. 8, p 6.

${ }^{20}$ Kanda et al., Official Commentary, Int-21.

${ }^{21}$ UNIDROIT 2002 - Study LXXVIII - Doc. 5, pp 1-4 and pp 7-10; UNIDroIT 2003 - Study LXXVIII Doc. 12, pp 5-17; UNIDROIT 2004 - Study LXXVIII - Doc. 19, p 7-11.

22 See e.g.: UnIDROIT 2003 - Study LXXVIII - Doc. 7; information about these fact finding missions can be found at http://www.unidroit.org/english/conventions/2009intermediatedsecurities/study78-archivee.htm (last visited 4 September 2013). 
are contributions by national delegations or organizations referring to particular instances of legal uncertainty. ${ }^{23}$

There is, however, also evidence that some national delegations and representatives were approaching their contributions with a view to preserving their own system rather than working out what concerns there were in terms of legal and systemic risk or in relations to market efficiency and what changes are required to address these concerns. ${ }^{24}$ Representatives of the French and German banking sector, for example, expressed in very clear terms that they would not want their national approach to change. It is worth noting that their respective and joint interventions were not substantiated by reference to legal risk, systemic risk or market efficiency. There is no analysis linking these contributions to the various instances of risk identified at the outset of the project. There is also no exploration as to the way in which a change would affect risk and efficiency and whether any change of national law would be outweighed by benefits that may come from that change. ${ }^{25}$ The Spanish delegation also pointed out that 'for Spain it is of the utmost importance that the project does not interfere with the legal regime on which the Spanish "double-tiered single registry system" is based'. ${ }^{26}$ Other examples are a contribution by Argentina requesting that the national rule that collateral can only be given to the intermediary by way of an entry on the securities account be integrated into the Convention and a similar contribution by Brazil that amendments be made to accommodate the local law requesting a book entry for a valid transfer of securities. ${ }^{27}$ Again these contributions are not engaging with a discussion on particular risk patterns or questions of market efficiency.

While there appear to have been distinct goals and also particular instances of risk that were on the minds of the drafters when the project began, the discussion appears to have moved away from these as the negotiation process progressed. Reading through some the national contributions it is easy to agree with the observation that 'law is a great protectionist technique'.28

To be sure, there may be reasons to object to change from the perspective of legal certainty, systemic risk or market efficiency. The fact that none of the contributors justified their intervention by reference to these reasons, but simply

\footnotetext{
${ }^{23}$ See e.g. the contribution made by the Deputy General Counsel of the Depository Trust \& Clearing Corporation UnIDROIT 2003 - Study LXXVIII - Doc. 11, pp 12-15.

${ }^{24}$ See e.g. the contributions made by Euroclear (UNIDROIT 2004 - Study LXXVIII - Doc. 16) concerning the liability of intermediaries.

25 Bundesverband Deutscher Banken (Unidroit 2004 - Study LXXVIII - Doc. 16) concerning the German 'proprietary co-ownership structure'; Fédération Bancaire Française jointly with the Association Française des Professionnels des Titres regarding the French system (UNIDroIT 2004 - Study LXXVIII Doc. 16, App 1) and also the joint statement of the Bundesverband Deutscher Banken, the Fédération Bancaire Française and the Association Française des Professionnels des Titres (UNIDROIT 2004 - Study LXXVIII - Document 16, App 1).

${ }^{26}$ UNIDROIT 2005 - Study LXXVIII - Doc. 20, p 7.

27 UnIDroit 2006 - Study LXXVIII - Doc 38, p 1 (Argentina) and UnIDroIT 2006 - Study LXXVIII Doc. 38, p 1 (Brazil).

${ }^{28}$ UnIDroit 2003 - Study LXXVIII - Doc. 12, p 9; see also Philipp Paech, 'Market needs as paradigm breaking up the thinking on EU securities law' in Pierre-Henri Conac, Ulrich Segna and Luc Thévenoz, Intermediated Securities (CUP 2013) 24-25.
} 
objected to change can suggest that their aim was to preserve the status quo irrespective of whether there were good reasons for doing so. It is also worth noting that the requirement for a 'political consensus' was on the minds of the study group and is also referred to in the Official Commentary. ${ }^{29}$

Notwithstanding the desire to create a framework that reduces legal and systemic risk and supports efficient markets, the rules contained in the Convention are the result of a decision making process between national delegations each of which was hesitant to change its own laws. It can also be speculated that the national delegations were mindful to preserve the business interests of their respective national industries. ${ }^{30}$

\section{(3) Common Principles Rather Than Reform}

At an early stage of the project the members of the study group discussed the idea to develop two documents. One document would be designed to contain only the rules necessary to improve the legal framework in cross border situations. The other document would be used to describe the standard for best practice at a national level helping national systems to identify shortcomings of their own legal framework and guiding them on how to make improvements. ${ }^{31}$ This approach was not implemented. Following the fact finding missions, a number of shortcomings of national systems would have been known to those working on the project. No attempt was made, however, to develop a framework that could serve as a benchmark allowing for a systematic evaluation of questions of legal uncertainty, systemic risk and market efficiency in relation to the existing legal regimes.

Moreover, no attempt was made to make a suggestion for a system, which against the background of modern technology would work best both at a national level and also in terms of compatibility across borders and what other systems could learn from it. It is, for example, quite possible that modern technology has rendered intermediation unnecessary and that ultimate customers would and should be able to hold securities directly with a central provider without the need to interpose and pay for layers of service providers.

Notwithstanding the aims stated at the beginning of the Convention, the reality of the negotiating and drafting process does not appear to have made it possible to systematically determine weaknesses of any particular system or cross border arrangement and to evaluate and address these against the background of legal certainty, systemic risk or market efficiency. The Convention appears more like the product of an attempt to set out the common principles prevailing in the

\footnotetext{
${ }^{29}$ Kanda et al., Official Commentary, Int-21; see also UnIDroIT 2002 - Study LXXVIII - Doc. 5, pp 5 and 7; UNIDROIT 2003 - Study LXXVIII - Doc. 12, pp 1-3.

${ }^{30}$ see also Philipp Paech, 'Market needs as paradigm - breaking up the thinking on EU securities law' in Pierre-Henri Conac, Ulrich Segna and Luc Thévenoz, Intermediated Securities (CUP 2013) 25.

31 UNIDROIT 2003 - Study LXXVIII - Doc. 11.
} 
jurisdictions concerned rather than as a document addressing particular legal problems that have been previously identified in these jurisdictions.

A focus on finding a common denominator of existing securities regimes is visible from the material documenting the drafting process. Great care was, for example, taken to ensure that the rules of the Convention did not interfere with the so called 'transparent systems' that operate in countries such as Brazil, Columbia, China, Czech Republic, Greece, Malta, the Nordic Countries, South Africa and partly in the United Kingdom. The issues arising out of transparent systems were discussed in detail at the fourth session of the Committee of Governmental Experts and special provisions were added to accommodate these systems. ${ }^{32}$

Another example is the genesis of Articles 11 and 12 GSC. The wording contained in the first draft was modified because a number of delegations were concerned that the Convention might displace or disrupt national provisions relating to net settlement. Article 11(5) GSC was introduced to provide that nothing in the Convention limits the effectiveness of debits and credits to securities accounts which are affected on a net basis in relation to securities of the same description. 33

Article 12 GSC provides for three methods which can be used to create a security interest or a limited interest, or for a transfer. Article 12 GSC was amended during the drafting process to accommodate the fact that the methods now contained in Article 12(3) GSC were used for purposes wider than the creation of a security interest in some jurisdictions. They were used to confer usufruct, a life interest or in the context of repurchase agreements. These interventions led to a widening of the scope of Article 12 GSC.

It has already been mentioned that there are good reasons to be careful about amending local law and market practice. Change can introduce new uncertainties. New rules should be introduced only after consideration of whether the risk of disruption of the existing mechanism is outweighed by the predicted decrease in risk and increase in efficiency. Interestingly, such an analysis was not carried out when the drafts were amended. The justification for amending the existing draft was simply that national rules or practices existed and therefore had to be integrated. No attempt was made to also justify the amendments in terms of the overall aims of the Convention and to evaluate the national practices in light of these aims.

Another illustration for the observation that the Convention contains a set of principles which States and observers could agree on without having to make

\footnotetext{
${ }^{32}$ Kanda et al., Official Commentary, Int-28, Int-30; significant time was spent during the drafting process to research how the existing transparent systems operated and how the Convention can be adapted to their requirements.

${ }^{33}$ Kanda et al., Official Commentary, 11-7.
} 
significant change to their national systems are the frequent references to nonConvention law and other sources of law outside the GSC. ${ }^{34}$

Examples that can be found in the context of the rules on securities transfers include: What constitutes a debit or credit is a matter for non-Convention law. ${ }^{35}$ Invalidity, reversal and conditions of debits, credits and designated entry are determined by non-Convention law (Article 16 GSC). ${ }^{36}$ Non-Convention law also determines the consequences of an unauthorized debit. ${ }^{37}$ The Convention does not set out whom the issuer is required to recognize as a shareholder. ${ }^{38}$ The Convention does not allocate the loss to an intermediary which may result from the reversal of a transfer.

The significance of national law appears to have increased as negotiations went on. The Austrian delegation observed towards the end of the drafting process that, " $\Pi \mathrm{t}$ must be noted that in the course of the negotiations an increasing number of items has been subjected to the "non-Convention law". 39 The references to non-Convention law are, again, not explained by an evaluation of risk or market efficiency.

A desire to create common principles rather than finding and addressing instances of risk and inefficiencies of the existing framework is also visible in individual articles of the Convention. Looking at the provisions this paper is designed to focus on, the articles on perfecting a security interest provide for a good example.

The Convention sets out three methods of transferring or creating a security interest in intermediated securities in Article 12(3) GSC. These are: If the interest is created in favour of the intermediary an agreement with the intermediary suffices. If the interest is created in favour of another person a designating entry in favour of that person needs to be made or a control agreement in favour of that person needs to be entered into. Contracting States may decide which of these three options to accept, but must not impose further steps in relation to any of them. It is to the credit of the Convention that formal requirements such as registration requirements or filing with a governmental agency, notarization by a public notary or publication in an official gazette or on the internet are not on the list. 40

The list, nevertheless, contains a summary of the main methods of perfection for a securities interest that exist in the jurisdictions that form part of the focus of

\footnotetext{
${ }^{34}$ For a comprehensive overview of the references to sources of law outside the GSC see: UNIDROIT Committee on emerging markets issues, follow-up and implementation, 'Information for Contracting States in respect of the Convention's references to sources of law outside the Convention, Document UNIDROIT S78B/CEM/2/Doc. 2 (November 2011).

35 Kanda et al., Official Commentary, 17-7.

36 Kanda et al., Official Commentary, 16-9 refers to Art 16 GSC as a 'prominent example of the limits inherent in the international harmonisation of the substantive law of intermediated securities'.

37 Kanda et al., Official Commentary, 15-18.

${ }^{38}$ Kanda et al., Official Commentary, 16-15.

39 UNIDROIT 2007 - Study LXXVIII - Doc. 90, p 1.

${ }^{40}$ Kanda et al., Official Commentary, 11-18 - 11-19.
} 
those drafting the Convention. The Convention does not attempt to cause Contracting States to change their law in this respect. Contracting States do not have to accept all of these methods in their jurisdiction. They can choose which ones they accept. Moreover, other methods of perfection may continue to create a valid interest notwithstanding the fact that they are not listed in the Convention (Article 13 GSC). This interest has lower priority than an interest created by a Convention method, but is still valid. ${ }^{41}$ One effect of Article 12(3) GSC is that Contracting States have to choose one or more of the methods listed. While it is possible that in some legal systems not all of these methods are valid methods it is highly unlikely that many jurisdictions exist that do not currently recognize at least one of these methods. Using the opting out mechanism has the effect of allowing Contracting States to preserve their own system to a significant extent.

\section{(4) CONCLUSIONS}

It seems that questions of legal certainty, systemic risk and market efficiency, while probably having continued to be on the minds of the national delegations, have not been as directly and systematically identified and addressed at the negotiation stage of the project as was intended by the members of the study group at the start of the project. Notwithstanding what the study group intended, the Convention appears to have developed into a text that sets out common principles of existing frameworks rather than reforming the local markets, the local legal regimes or the existing cross-border arrangements.

\section{IMPACT OF THE CONVENTION ON LEGAL CERTAINTY}

\section{(1) INTRODUCTION}

This is not to say that the Convention made no contribution. Although the Convention has not come into force yet and has so far been signed by only one jurisdiction, ${ }^{42}$ it seems that it can nevertheless assist legislators that have previously had no rules and would like to create a new framework from scratch. ${ }^{43}$ Perhaps the most important contribution of the Convention is the starting point of its analysis. Given that securities are held through accounts, approaching the topic from the perspective of securities accounts fits well with the topic. Designing entries on accounts in a way that makes them resistant to claims from the intermediary's creditors and other adverse claims reflects the current practice in

\footnotetext{
${ }^{41}$ Kanda et al., Official Commentary, 19-13 and 13-5.

42 The status of the Convention can be found at http://www.unidroit.org/english/implement/imain.htm (last visited 4 September 2013).

43 It will be shown below, however, that those using the Convention as an inspiration for legislation need to be careful to draft a text that fits with the local legal framework [see para 0 to 0 ].
} 
securities markets better than an analysis build on the property law of tangible or intangible objects.

The Convention and also the analysis carried out during the UNIDROIT project made a significant contribution by collecting information on how different systems operate. It is also very instructive and helpful from the perspective of comparative law to have a set of rules that reflect the common understanding of most jurisdictions on this area of the law.

Another important contribution made by the Convention is that it shows how much can be achieved through a process of law reform on a consensual basis. The Convention is the product of a monumental effort to persuade national delegations from across the world to agree on a common framework. It is to the great credit of those running the project that a final text was adopted that the UNIDROIT member States felt able to accept. It is also fair to conclude that we now have a very good understanding of what can be achieved by harmonizing legal rules without reforming the existing set up of the market infrastructure.

The purpose of this section is to determine to what extent the Convention has increased legal certainty. Has it made it possible to draft more reliable documentation and legal opinions? Has it helped to resolve issues of legal certainty at a national level? It will be shown that the Convention has not made a significant contribution to legal certainty and that it is unlikely that further progress can be achieved by the harmonization of legal rules. This is an important insight that helps to determine how to proceed in the future.

\section{FUNCTIONAL APPROACH}

The Convention has adopted what has been termed a 'functional approach'. The sixth recital of the Convention explains 'that a functional approach in the formulation of rules to accommodate the various legal traditions involved would best serve the purposes of the Convention'. The Official Commentary adds that different jurisdictions have different legal formulations, doctrines and histories in relation to intermediated securities. The Convention does not attempt to harmonize these. It is rather intended to harmonize the result of the rules on certain key matters while allowing the Contracting States to maintain or adopt their own legal doctrines. ${ }^{44}$ The drafters of the Convention attempted to use language that was considered to be neutral. Neutral language in this context is best understood as language that is different from the language used in any of the jurisdictions considered in the drafting process. Rules are formulated by reference to their results rather than by reference to local legal concepts. In order to avoid using terms that have a particular technical meaning in one jurisdiction the drafters stayed clear, for example, of notions of 'property', 'ownership' or 'equitable interest'. The hope was that this would avoid confusion which, it was felt, 'can

${ }^{44}$ Kanda et al., Official Commentary, P-7. 
easily arise from the different traditions and conceptual frameworks of the different systems of law'. ${ }^{5}$ It has also been observed that the functional approach helped to overcome the 'vast differences in the legal doctrine affecting intermediated securities holding systems' and market structures and also 'outright hostility to and obstruction of the project on the part of one influential state participant, namely France'. 46

By introducing neutral language, the Convention attempts to avoid imposing ideas from one legal system onto another legal system. The neutral language introduced by the Convention, however, does not automatically increase certainty and also does not in and of itself eliminate confusion.

The concepts introduced by the Convention require interpretation. This inevitably creates uncertainty. New rules initially also introduce new questions because they require interpretation to determine their scope of application against the background of the existing framework. This is a price worth paying if the uncertainties eliminated by the Convention outweigh the uncertainties created by the Convention.

It seems, however, that the functional approach does not do much to eliminate uncertainty. It will be shown below that the functional approach is only able to make a very limited contribution. ${ }^{47}$ This is because it does not significantly help those drafting documentation and legal opinion or national legislation to improve the quality of their work.

The Convention sets out outcomes that are to be created by means of national legislation. This requires national legislators to become active to modify their laws to produce the desired outcomes. Those drafting documentation and writing legal opinions will continue to have to investigate the national framework. It will be shown below that their work will not be easier and that their documents will not be more reliable as a result of the Convention.

Article 11(1) GSC, for example, provides that an account holder acquires intermediated securities by a credit of these securities to that account holder's securities account. Contracting States may not require further steps in addition to a credit, but they may specify what constitutes a credit (Article 11(2) GSC).48 Contracting States therefore need to determine how a requirement for a further step (which is banned) is to be distinguished from the specification of what amounts to a credit (which is allowed) and that is a new problem of construction that increases the level of legal uncertainty.

\footnotetext{
${ }^{45}$ Kanda et al., Official Commentary, Int-20.

${ }^{46}$ Charles W Mooney, jr, 'The truth about shortfall of intermediated securities - perspectives under the Geneva Securities Convention, United States law and the future EU legislation', in see also Philipp Paech, 'Market needs as paradigm - breaking up the thinking on EU securities law' in Pierre-Henri Conac, Ulrich Segna and Luc Thévenoz, Intermediated Securities (CUP 2013) 160-161 and fn 3.

47 See also Dorothee Einsele, 'Intermediaer-verwahrte Wertpapiere, Rechtsharmonisierung versus Systemneutralitaet' 177 (2013) Zeitschrift fuer das gesamte Handels- und Wirtschaftsrecht 50-89.

${ }^{48}$ Kanda et al., Official Commentary, 18-10; Luc Thévenoz, 'Transfer of intermediated securities' in PierreHenri Conac, Ulrich Segna and Luc Thévenoz, Intermediated Securities (CUP 2013) 147-150.
} 
A straightforward example for what is banned can be found in the context of Article 18 GSC. Article 18 GSC protects the acquirer of securities against adverse claims provided that he acquired the securities for value and acted in good faith. A Contracting State should not undermine the protection of the Convention by making the validity of a credit dependent upon the validity of a previous credit. ${ }^{49}$

There are, however, also less straightforward questions of construction to be solved by Contracting States in this context. German law, for example, contains a requirement for a contract in rem to be validly concluded for securities to be transferred. It would appear that a 'contract in rem' in addition to an 'obligational contract' would be characterized as an additional step required for the transfer, but that was apparently not intended by the drafters. The Official Commentary, therefore, sets out that it is 'understood' that non-Convention law may make the validity of a credit dependent on the validity of the transaction or any related agreement, such as an agreement in rem which the credit purports to fulfil. Such validity requirements therefore are not 'further steps' prohibited by Article 11(2) GSC. 50

This illustrates the difficulty with functional language. The boundaries of the new functional term need to be determined in relation to the concepts existing in every Contracting State. Unlike in the context of EU directives, there is also no mechanism ensuring that the new term will be understood in the same way by the different Contracting States. It is highly likely that starting the analysis against the background of their own framework different Contracting States will develop their own distinct way of interpreting the provisions of the Convention. Lawyers drafting documentation and writing legal opinions must not put in place wording or reach conclusions at a broad brush functional level. Detail matters. Even if all jurisdictions have attempted in good faith to attribute the characteristics provided for in the Convention to a credit, any lawyer looking at another system will still need to determine in which instances precisely a credit occurs and also to what extent exactly the characteristics suggested by the Convention can be identified in the local law and how certain these conclusions are against the background of the local framework.

In relation to German law, for example, foreign lawyers will have to work out how the national law has defined the point in time at which securities are acquired. Then they need to determine what is meant by a 'contract in rem', at what point this contract becomes binding, what happens if such a contract is invalid and how to translate these notions into their own system. Moreover, even if the Contracting State has stepped over the line and requires further steps, there is nothing that can be done about that at least as far as the courts of the country that acted contrary to the Convention are concerned. From the perspective of the lawyers operating in

${ }^{49}$ Kanda et al., Official Commentary, 18-10.

${ }^{50}$ Kanda et al., Official Commentary, 11-12. 
this area this possibility needs to be investigated and taken into account regardless of whether it is in violation of the Convention or not.

Certain conclusions, which are necessary to create robust documentation and reliable legal opinions, can only be drawn from precisely drafted laws. Results formulated in functional terms provide some guidance on what local laws should roughly aim for, but do not help to create certain outcomes. The best that can be achieved at a functional level is a rough level of similarity that is interesting but does not help those having to master the detail. The worst that can come out of this process is an illusion of similarity in the minds of lawyers who do not have the skill or have not been given the resources to carry out adequate research and this is more dangerous in terms of legal risk than certainty that there are differences that require careful attention.

Another example is Article 14(1) GSC which states that rights and interests that have become effective against third parties according to Convention rules are also effective in the insolvency of the intermediary. This, however, does not affect the application of any substantive or procedural rule of the law applicable by virtue of an insolvency proceeding (Article 14(2) GSC). The Convention goes on to give examples of what is meant by 'substantive or procedural rules' of insolvency proceedings. The examples referred to are: the ranking of categories of claims, the avoidance of transactions as a preference or fraud on creditors or the enforcement of rights of property that is under the control or supervision of the insolvency administrator. Defining what qualifies as a substantive or procedural rule of insolvency law in this context is important because such rules could be used by Contracting States to require 'further steps' in addition to those listed in Article 12 GSC to be complied with for the creation of a valid interest. ${ }^{51}$ The Official Commentary explains that it would be impossible to codify in the Convention text a complete listing of exceptions that would prove satisfactory to all Contracting States. Such a list would be both over- and under-inclusive when taking into account the varying approaches and policies of the Contracting States. ${ }^{52}$ The Official Commentary concludes that it is inevitable that in some situations it will be unclear whether a relevant rule of law is triggered by an insolvency proceeding. ${ }^{53}$ It then goes on to recommend that Contracting States when joining the Convention change their law to clarify which rules are covered by the exception contained in Article 14(2) GSC.54

Even if the Convention is implemented across the world, those drafting documentation and legal opinions still have to develop a deep understanding of the insolvency laws of other jurisdictions to determine precisely to what extent insolvency proceedings affect the rights of investors. The devil lies in the most minute of details. Lawyers would be negligent to rely on the fact that any particular country has joined the Convention to conclude that investors are therefore

${ }^{51}$ Kanda et al., Official Commentary, 14-8 and 14-9.

${ }^{52}$ Kanda et al., Official Commentary, 14-7.

${ }^{53}$ Kanda et al., Official Commentary, 14-9.

${ }^{54}$ Kanda et al., Official Commentary, 14-10. 
protected in the insolvency of an intermediary. The Convention has not made their work easier and there continues to be ample room for the misunderstanding of local rules.

Art 18 GSC protects an acquirer for value against adverse claims unless he knows or ought to know of the interest of another person. The GSC adopts its own notion of 'good faith'. The Official Commentary warns that courts should be aware that guidance from the applicable law with respect to the good faith purchase of movables more generally may not be appropriate. ${ }^{55}$ In attempting to explain what is meant by 'ought to know' the Official Commentary sets out that 'no simple example that does not assume actual knowledge can be sufficiently rich in factual detail to support a definite conclusion on the "ought to know" issue. 56 Article 17(c) GSC attempts to identify the circumstances in which an organization knows or ought to know of an interest or fact and states that this occurs 'when the interest of fact is or ought reasonably to have been brought to the attention of the individual responsible for the matter to which the interest of fact is relevant'.

It is not straightforward to determine what is meant by 'ought to know', 'reasonable' or 'individual responsible'. ${ }^{57}$ These notions will require further clarification at a national level and it is unlikely that they will be understood in the same way across the globe.

The Convention shows national legislators some of the results they should aim for, but it does not help those working towards creating certain legal documents for the markets. The level of legal certainty is to a significant extent dependent upon the documentation used by the parties concerned. The recent UK decision in Eckerle shows how even very sophisticated parties can fail to implement contractual rules that produce outcome that on the face of it all parties concerned must have intended to achieve.

This is because it is not difficult to gain a functional understanding of a foreign jurisdiction. Most lawyers working in the area will have achieved that within a fairly short span of time. What is more difficult is to appreciate the implications of small detail and that continues to require a high level of understanding of national rules which are well outside the scope of the Convention. But even within the scope of the Convention the functional approach does not allow lawyers to conclude that the result set out in the Convention has been implemented to a sufficient level of certainty.

Also the help provided by the Convention for the improvement of domestic rules is limited. This point can be illustrated by reference to English law. English law does not have a rule protecting the good faith purchaser of an equitable interest against adverse claims. It is possible for an acquirer of intermediated

\footnotetext{
55 Kanda et al., Official Commentary, 17-7.

56 Kanda et al., Official Commentary, 17-12 and 20-10.

${ }^{57}$ Kanda et al., Official Commentary, 17-19.
} 
securities to find that his holdings are subject to an earlier defective entry. ${ }^{58}$ The English are aware of this problem. ${ }^{59}$

The Official Commentary sets out that the Convention aims to address it. It states that the Convention is designed to immunize the acquirer from such claims provided he does not know and ought not to know of an earlier defective entry and provided he did not acquire by way of gift or otherwise gratuitously. ${ }^{60}$ Does the Convention help England?

The Convention confirms that it would be right for England to do something about this. But that in itself does not increase legal certainty. Legal certainty can only be increased by precise wording that fits with the national legislation. In terms of drafting a solution that sits squarely with the existing regime the Convention does not help. The wording protecting the acquirer at national level needs to be chosen carefully in light of the existing regime using local and not functional language. Anything else would not increase but reduce legal certainty. Those drafting legislation should not use the wording of the Convention and reproduce it in the national piece of legislation.

Interestingly, this point was raised by the Russian Federation during negotiations. Under Russian law, international treaties automatically become part of national law. There is no constitutional requirement for the Russian Federation to pass a specific act transforming international treaties into local law. The Russian delegation made the point that this will make it difficult for Russia to join the Convention 'because the terms and legal conceptions used in the draft Convention are unknown to the Russian law.' ${ }^{61}$

To achieve legal certainty the solution put in place at national level must not rely on Convention wording. Any solution must be developed out of the existing framework. There is a risk that sloppy drafters might be tempted to copy and paste Convention rules and cause significant problems in national legislation that would increase the level of uncertainty rather than decrease it.

\section{(3) Non-Convention Law / Sources of Law Outside the CONVENTION}

References to non-Convention law which have already been mentioned because their number increased during the drafting process also do not help to increase legal certainty. Given that the functional approach already limits the effect of the Convention to a significant extent, the impact of the Convention is reduced even further when references to other sources of law are high in number.

\footnotetext{
${ }^{58}$ Kanda et al., Official Commentary, 18-7.

${ }^{59}$ See the project of the Law Commission on Property Interests in Intermediated Securities, materials are available at http://lawcommission.justice.gov.uk/areas/property-interests-in-intermediate-securities.htm (last visited 4 September 2013).

${ }^{60}$ Kanda et al., Official Commentary, 18-7.

${ }^{61}$ UnIDROIT 2006 - Study LXXVIII - Doc. 52, p 1.
} 
This can be illustrated by an analysis of Article 11 GSC. Article 11 GSC, which states that securities are acquired by the credit to an account, is subject to Article 16 which refers to non-Convention law and to the extent permitted by non-Convention law the account agreement or the uniform rules of the securities settlement system determine whether and in what circumstances a debit, credit, designating entry or removal of designating entry is invalid, is liable to be reversed or may be subject to a condition and the consequences thereof. The Convention also does not determine the nature of the interest acquired. A transfer can therefore be analyzed in terms of transferring property from A to B but also in terms of extinguishing an interest for the benefit of $\mathrm{A}$ and creating a new interest for the benefit of B. ${ }^{62}$ Problems that arise in the context of a cross border situation between jurisdictions that use a transfer approach and jurisdictions that use a novation approach are as a result not resolved by the Convention.

These are important matters affecting the rights of investors. If the notion of what precisely constitutes a credit, the point in time at which such a credit becomes valid, its substantive validity, its reversibility and the effect of conditions are left outside the scope of the Convention, the contribution of the Convention is reduced to the insight that what matters are robust entries on accounts. This is an important insight. The Convention, however, only says that they should be robust. The creation of the framework to support such entries is largely left to national law, which can be misunderstood and will have to be meticulously researched for documentation and legal opinions to provide legal certainty.

There are also a number of matters in the context of priority of security interests that are outside the scope of the Convention.

Article 12(3) GSC sets out three methods of perfection for an interest in intermediated securities. It has already been mentioned that Contracting States can choose which of those methods they accept. Their respective choices have an impact on the priority rules in Article 19 GSC and can make the analysis more complex in relation to priorities. ${ }^{63}$ Non-consensual security interests such as a vendor's lien are not defined by the Convention and the priority of such interests will be determined by the applicable law. ${ }^{64}$ Moreover, Contracting States may provide further methods of perfection (Article 13 GSC). Admittedly, interests perfected according to Article 12 GSC have priority over interests created by nonConvention law. ${ }^{65}$ The innocent acquirer of intermediated securities or an interest therein is protected against prior and later interests created by non-Convention law. ${ }^{66}$ The acquirer of a Convention Article 12 interest also has priority over later interests that have been created according to non-Convention law because of

\footnotetext{
62 Kanda et al., Official Commentary, 11-4.

${ }^{63}$ Kanda et al., Official Commentary, 19-10.

${ }^{64}$ Kanda et al., Official Commentary, 19-5.

${ }^{65}$ Kanda et al., Official Commentary, 19-13.

${ }^{66}$ For a discussion of the relationship between the rule protecting the good faith acquirer and Art 19 see Spiros Bazina in Thomas Keijser, Transnational Securities Law, OUP 2014
} 
Article 19(2) GSC. ${ }^{67}$ It also is worth noting that buyers or collateral takers that have acquired their interest using a non-Convention method are not protected by the Convention rules on innocent acquisition of an interest. ${ }^{68}$

Lawyers advising in this area need to work out which option or which options a particular Contracting State has selected and how they have defined the parameters of the option or options. They will also have to determine the extent to which non-consensual security interests exist and how they affect other interests. In addition they would be ill-advised not to get clarity on the priority of interests created by non-Convention law. It would not be safe for a lawyer not to determine if these interests do in fact have the reduced effect set out in the Convention.

Frequent references to non-Convention law increase the instances in which foreign lawyers need to understand national rules to draw conclusions upon which they write an opinion or select wording for documentation.

\section{(4) CONCLUSIONS}

The Convention does not help to overcome the problem of synchronizing contracts over levels of multiple intermediaries. This problem will continue to exist as long as there are multiple layers of intermediaries and it is aggravated by each intermediary that is added to the chain. The Convention also does not address the problem of drafting documentation with a view to linking transactions across borders.

The Convention uses a functional approach and abstains deliberately from using or explaining the concepts prevailing in different jurisdictions. The Convention aims to harmonize results thereby hoping to create a situation where notwithstanding differences in laws the outcomes are the same. While this may cause different systems to achieve identical or at least similar outcomes to a greater extent than is the case already, it does not reduce differences between national laws and the legal cost arising from these differences. Lawyers cannot conclude that their clients are protected on the basis of the analysis that the Convention has been implemented and that the results achieved by the Contracting States are therefore functionally the same. Neutral language creating a functional model does not increase legal certainty. Legal certainty requires precise language.

Those giving legal advice to market participants will continue to have to analyze the national rules to the same level of detail as before. The Convention adds to the analysis they need to carry out because legal advisors in addition to understanding the foreign framework and approach need to determine the extent to which the provisions of the Convention have been implemented and also how well this implementation fits with the existing framework. There continues to be plenty of room for misunderstanding national rules. The problem that at each level

${ }^{67}$ Kanda et al., Official Commentary, 19-13.

${ }^{68}$ Kanda et al., Official Commentary, 13-5. 
the documentation protects also the interests of the intermediary concerned and so waters down the interest of the ultimate beneficiary will continue to exist and will continue to be aggravated with the length of the chain.

\section{E. WHAT WOULD WORK?}

Leaving aside the question as to whether political consensus can be found, would it help to harmonize the law further? The conclusion of this chapter is that it would not. This is because further refinement of common harmonized rules perpetuates rather than resolves the problem. The Convention has made a very important contribution by showing how far harmonization of law can improve the existing intermediated framework. This has shown that some but not significant progress can be achieved through that route.

The starting point towards a solution reducing the cost and uncertainties arising out of intermediation has to be that the number of intermediaries needs to be reduced and also that a direct connection between issuers and intermediaries has to be created. Having determined that there are significant limits to how much harmonization can be achieved at a functional level, it is worth asking if it is possible to create a system which reduces the number of intermediaries operating between issuers and investors and also enables investors to directly connect with issuers.

It seems that a point has been reached where it would be appropriate for policy intervention at least at a European level facilitating the emergence of a direct and transparent settlement and holding system.

\section{F. TARGET 2 SECURITIES}

The European Central Bank started a project in 2006 exploring the possibility to create a pan-European service for securities settlement in the euro area. A list of specifications setting out such a service was published in September 2012.69 The development and testing phase began in April 2009 and is scheduled to end in March 2014. User testing is going to begin in March 2014. The plan is for T2S to go live in the first half of 2015. At that point the first group of central securities depositories will start operations on the platform.

The idea is to create a computer programme for central securities depositories, central banks, custodians and other intermediaries to process their

69 Available at http://www.ecb.int/paym/t2s/progplan/html/index.en.html (last visited 4 September 2013). 
respective transfers and record their respective securities holdings. Users will, for example, operate to the same time table and use the ISO 20022 messages format. The hope is that this will relieve market participants from the requirement to pay for back office facilities that accommodate different software specifications. It is also hoped that this will enable market participants to move securities more quickly and cheaply between markets to, for example, deliver collateral that is presently not needed in one market to another market where it is required.

The plan is for the target2securities project to be supplemented by an EU regulation on Central Securities Depositories. This regulation is designed to abolish national monopolies and enable central securities depositories and other intermediaries to operate in all markets. ${ }^{70}$ The regulation also introduces an obligation of dematerialization for most securities, harmonized settlement periods for most transactions in such securities, settlement discipline measures and common rules for central securities depositories.

The hope is that the combined effect of a software platform that connects intermediaries across border and the abolition of national monopolies should facilitate competition between market participants and can, over time, also lead to a reduction of numbers of national players. It will be possible for globally acting intermediaries to offer their services directly without having to connect to a national hub with monopoly status. It will also be possible for smaller national providers to offer their services at an international level to challenge the current market leaders.

This may help to reduce the number of intermediaries. It is worth noting, however, that in the context of the Eckerle case Clearstream would have been able to operate as the UK central securities hub. The UK does not operate a monopolistic settlement regime. Under the Uncertificated Securities Regulation Clearstream could at present apply to operate a system that competes with Crest. Clearstream would have to meet certain technological specifications, but is not prevented from accessing the market as a CSD. Clearstream has not yet chosen to go down that route however. It would appear that there are business reasons that currently make it unattractive for Clearstream to operate in the UK directly.

Moreover, it is not clear why the Bank of New York Depository (Nominees) Ltd was added to the chain of intermediaries in the Eckerle case. Clearstream would have been able to connect to CREST directly without the need for Bank of New York Depository (Nominees) Ltd to intermediate between them. Not very much is known about the economics explaining why long chains of intermediation have come into existence. ${ }^{71}$ It is possible that long chains of intermediaries have established themselves because of cost advantages between intermediaries who optimize their own cost base, but are not affected by the cost created by long

\footnotetext{
${ }^{70}$ Hubert de Vauplane and Jean-Pierre Yon, 'The concept of integrity in securities holding systems' in Pierre-Henri Conac, Ulrich Segna and Luc Thévenoz, Intermediated Securities (CUP 2013) 200-202.

${ }^{71}$ For an analysis of the US context see David C Donald, 'The Rise and Effect of the Indirect Holding Systems: How Corporate America Ceded its Shareholders to Intermediaries' 59-62 available at http://papers.ssrn.com/sol3/papers.cfm?abstract id=1017206 (last visited 4 September 2013).
} 
intermediation chains which are born by ultimate investors. There may also be other explanations connected with the fact that at present only a limited number of intermediaries operate across border in Europe. It is possible that it is not the interest of either of those to compete with the others. In those circumstances making it easier for the existing intermediaries to communicate with each other is unlikely to significantly reduce the length of intermediation chains.

The target2securities project perpetuates the current market infrastructure which relies on intransparent intermediation and disconnects issuers from ultimate investors. It also facilitates a line of business which intermediaries with a custody business have in the more recent past increasingly developed. It will help them to provide and promote the services of managing securities lending and tri-party repo transactions. The target2securities project does not investigate or address the incentives that have caused the current market infrastructure to emerge and investors will continue to work their way through a chain of intermediaries. Target2securities is not designed to better connect investors with issuers.

It seems that the right solution given that this is technically possible would be for a mechanism to be created whereby irrespective of whether intermediaries are position between issuers and investors the system for holding and transferring securities records the name of ultimate investors on their books. Given that reform is already under way to create a new computer programme for settlement, it would make sense to also fix the problem that investors are presently disconnected from issuers through intermediation at the same time. It would be also worth investigating the incentives that support the current market infrastructure. Levels of legal uncertainty would be significantly lower if there existed one central electronic system that held and transferred securities for all European jurisdictions and if that system was accessible directly by holders.

Until recently it would not have been possible to create such a system not even at a national level. For example, when intermediation started in Germany during the 1930s, the means of communication were at a stage of development that required intermediation. It was not possible to create a central system which could be accessed by all German investors. Investors accessed their holdings through local banks which held deposits with regional banks which held deposits with the central depository. While it was not possible to create such a system when Germany created its central intermediary, there is no reason to conclude that the need for intermediaries continues to exist today.

The same is true for the UK where, before CREST was put in place, it made sense to have shareholder registers administered in geographical proximity to issuers. UK issuers communicate with shareholders using the contact information contained in the register. Issuer need up to date information and prior to electronic means of communication that can best be achieved by placing the administration of the shareholder register in proximity to the issuer. Registrars developed as a branch of the financial services industry against the background of this requirement. This has changed. It is now possible to administer these holdings 
centrally. Uncertificated UK securities and their transfers are managed centrally through CREST, an electronic system. Interestingly, however, registrars continue to maintain registers for certificated securities. It seems likely that the management of the relatively small number of certificated securities could now also be managed centrally and perhaps at a lower cost.

At a European level the existing network of intermediaries was set up using methods that were created before electronic communication became possible. They have continued to operate notwithstanding the fact that it would now be possible to create a central European facility. This makes holding securities cross border expensive. The cost caused by inserting a significant number of intermediaries between issuers and investors did not matter much when cross border holdings were still infrequent. This cost did become a matter for discussion and possible reform, however, for the European Union which has set itself the policy objective to provide a framework which will facilitate a single European market. If the settlement and management of securities cross border are expensive that cost will be reflected in the terms under which issuers are able to raise money across the EU.

It is important to discuss law, but it seems that this discussion is futile unless it is accompanied by a discussion about structural reform. It is worth asking the question about what would happen if a settlement mechanism was created from scratch using modern means of technology and communication. This is a question best discussed at an academic and government policy level rather than in consultation with organizations that have a vested interest in preserving the status quo.

It is not a question to be put to existing intermediaries and other providers of the current market infrastructure. Existing market participants, for example the German and the French banking associations, have proven to be very committed to protecting their respective business models.

The fact that incumbent market participants are unable to bring about reform if the increased efficiency involves reducing their own market was also demonstrated in the UK when the paper settlement system Talisman collapsed. The London Stock Exchange and its participants spent seven years and a very large sum of money trying to set up an electronic settlement system keeping all incumbent providers of infrastructure happy and taking away business from no one and failed. The Bank of England had to step in and take over the reform process.

Consulting with existing intermediaries can only produce solutions that leave current levels of intermediation in place and is unlikely to produce a solution that reduces levels of intermediation. It seems that, at least at a European level, it would be right to go back to the Lamfalussy report and to conclude that the market has been unable to resolve the issue of excessive intermediation and it is now for policy makers to search for alternative solutions. ${ }^{72}$

${ }^{72}$ Lamfallussy Final Report (fn 2) 16. 